Marquette University

e-Publications@Marquette

Social and Cultural Sciences Faculty Research and

Publications

Social and Cultural Sciences, Department of

$1-1-2014$

Beyond the Dichotomy: Six Religious Views of Homosexuality

Dawne Moon

Marquette University, dawne.moon@marquette.edu

Accepted version. Journal of Homosexuality, Vol. 61, No. 9 (2014): 1215-1241. DOI. (C) 2014 Taylor $\&$ Francis (Routledge). Used with permission. 


\title{
Beyond the Dichotomy: Six Religious Views of Homosexuality
}

\author{
Dawne Moon, PhD \\ Department of Social \& Cultural Sciences, Marquette University \\ Milwaukee, WI
}

\begin{abstract}
:
Using published theological and scholarly evidence, this article disrupts the stereotypical "born-gay"/ "sinful choice" dichotomy widely assumed to characterize religious views of homosexuality in the United States. It argues that we need to keep moral questions separate from questions about the fixity or fluidity of sexual orientation. Rather than two, American Christian and Jewish views of homosexuality can been seen on a range from the "God Hates Fags" view, through "Love the Sinner, Hate the Sin," "We Don't Talk About That," "They Can't Help It," "God's Good Gift" and a queer-theological view of the "Godly Calling."
\end{abstract}

Keywords: homosexuality, Christianity, Judaism, moral, sexual fluidity, queer, LGBT, religion, everyday theologies.

When it comes to religious views of homosexuality, the American public tends to think of a binary opposition, pro-gay and anti-. In reality, Americans' views are not so dichotomous (DiMaggio et al 1996; McConkey, 2001; Williams, 1997) and the idea that they are promotes stereotypes, exacerbates conflicts, and compounds confusion. Since religious views tend to inform much of public debate about homosexuality, a more nuanced understanding of them may 
help us to have more meaningful and productive discussions in many arenas.

In what follows, I lay out six types of U.S. religious view of homosexuality, ranging from the "God Hates Fags" view, through "Love the Sinner, Hate the Sin," "We Don't Talk About That," "They Can't Help It," "God's Good Gift" and finally, a queer-theological view of the "Godly Calling." A range of subtle perspectives can be observed in many religious traditionsi, but I focus on Christian and Jewish views here; these communities have been challenged to accommodate lesbian and gay members in a positive way over the past fifty or so years (White, 2008) ${ }^{i i}$, and thus have developed elaborate and wideranging arguments that most directly influence public discussions in the U.S. This list of types does not capture every religious view, even in the U.S. alone, and a brief discussion that elaborates nuance in one area unfortunately obscures a great deal as well; more subtlety appears in many of the texts cited or elsewhere.

I write from the position of a sociologist who has studied religious debates about homosexuality in the U.S., and while my own views will be clear, my goal is to present each view in its own terms. Other social-scientific studies of religion and homosexuality tend to focus on either LGBTiii and/or queer religious people themselves, or on homonegativeiv religious groups, and thus focus on only one side of the controversy at a time. By bringing together perspectives that rarely appear in the same place, I hope to provide a resource for researchers, clinicians, students, and others interested in debates about homosexuality, both within religious groups and in secular settings where religious arguments inform the discussion.

\section{Thinking Clearly About Sexuality: Recognizing Differences}

Scholarship on the origins of same-sex desire reveals a complicated mix of physiological and social factors contributing to homosexuality (Fausto-Sterling, 2000; Jenkins, 2010; Tolman, \& Diamond 2001). Over the past decades of heated debate in the United States, popular views of homosexuality have largely crystallized into two opposing arguments, with the "pro-gay" side insisting that gay, lesbian, and bisexual people are born that way and cannot change- 
expressing what I call the "born gay" argument-and those who believe homosexuality to be sinful insisting that any non-heterosexual identity can and should be changed-what I call the "sinful choice" argument (Haider-Markel \& Joslyn, 2008). This dichotomy obscures many differences within each category and similarities across categories. Furthermore, it attaches understandings about sexual fluidity to particular moral evaluations of non-heterosexual identity, desire and/or sexual behavior.

If we are truly to understand the range of views on sexuality, we must decouple arguments about the fixity or fluidity of sexuality from arguments about the morality of same-sex sexual behavior and the moral worth of gay, lesbian, bisexual, or transgender identity. Indeed, it is possible to believe that some people are inherently homosexual, and that homosexuality is sinful and evil. Likewise, it is possible to believe that some people may experience their sexual identity as "chosen" in some way-or that sexual behavior, attraction, and identification can change throughout the life course-and to maintain that gayness, bisexuality, lesbianism, transgenderism, queerness, and/or gender or sexual fluidity are morally neutral or good.

The very possibility that anyone might experience sexual fluidity often provokes a sense of threat for lesbian, gay, transgender and allied people, because the possibility of change has been so closely wedded to the belief that if any gay man or lesbian's sexual orientation can change, all lesbian, gay, and bisexual people should become heterosexual (without transitioning to another sex category) (HaiderMarkel \& Joslyn, 2008; Weiner, Perry \& Magnusson, 1988). Stories of change are often used coercively by authorities who see homosexuality as sinful and/or sick, and attempting to change at will has been painful and disastrous for many LGBT people. However, not all change carries that moral judgment, and accepting that variation exists makes it easier to understand different views. Blumstein and Schwartz (2000) interviewed people who had had sexual experiences with both men and women and found that their self-definitions varied widely; over the life course a person might identify as heterosexual at one point, homosexual at another, or bisexual at another, and these identifications depended on their situation and the meaning others ascribed to these various categories. ${ }^{\vee}$ Such changes need not reflect a 
negative judgment of same-sex sexual behavior or LGBT identities. Clearly, some people experience change and others cannot, even if they try.

\section{Six Religious Views of Homosexuality}

Just as people vary widely in terms of sexual experience, attraction, and identification, their religious views of homosexuality also vary widely. The "sinful choice" and "born-gay" views are perhaps the most familiar and widespread, but they are not the only two views held in religious communities. I have drawn from published theological analyses and ethnographic studies (which help to locate the "everyday" or unofficial theologies of believers in their day-to-day lives [Moon 2004]), and lay out six types of religious views of homosexuality present among U.S. Christians and Jews. Including everyday theologies is warranted in part by the decrease in the significance of institutional religious authorities in the lives of many Americans (and others) and the increase in lived religiosity, or "spirituality" (Dillon, 1996; Wilcox, 2003; Yamane, 1997; Yip, 2002). My sample of texts is not exhaustive, but it is sufficient to my purposes of disrupting the "born gay" versus "sinful choice" dichotomy. This approach does not tell us what proportion of American Jews and Christians hold, avow, or act on any of these views, but that is a subject for a different study. As a first step, we need more clarity about the range of views that exist.

In general those who see homosexuality as sinful tend to refer to roughly three passages from the Hebrew Bible (Genesis 19:1-29, Leviticus 18:22 and 20:13); Christians also refer to Romans 1: 26-27, I Corinthians 6:9, and I Timothy 1:9-10 in the New Testament. They see these passages as clearly prohibiting same-sex sexual behavior for all time-either for all of humanity, or for their particular community. Those who do not believe homosexuality to be sinful tend to believe that scripture was divinely inspired but that human beings' understandings of its apparent discussions of homosexuality are constrained by culture, historical context, language, and perception. vi

The six views I present are ideal types. As Figure 1 depicts, this six-part typology may be represented visually as a spectrum from hostile to celebratory. vii [Figure 1 about here.] An individual may change her mind, hold contradictory views, or have a perfectly 
coherent view that draws from more than one of my categories. This typology does not exhaust every religious argument about homosexuality, nor should it be used to pigeonhole religious views as people encounter them. It should be understood as a heuristic tool to help us to ask informed questions and sort out some of the nuances in religious views of homosexuality, particularly as they relate to questions of sin, choice, and sexual fluidity. Future scholarship should develop each of these views, and modify the typology as needed.

\section{Homonegative Views}

The first two views posit homosexuality, or at least same-sex sexual behavior, as unambiguously sinful. Clearly, many religious people in the United States believe that same-sex sexual behavior is forbidden in scripture, which they also see as revealing God's intention that male and female are complementary. For some, homosexual desire is itself sinful and evil, while others see only same-sex sexual behavior as sinful. The key to distinguishing these first two viewpoints is in whether they see any place at all for LGBT people in the religious community.

\section{"God Hates Fags"}

The first view presented in Figure 1 sees no place for same-sex attractions among the faithful. This view has been spectacularly represented by the Reverend Fred Phelps and his Westboro Baptist Church's protests of homopositive churches and the funerals of prominent gay people and their allies. Slogans such as "God Hates Fags" and "Fags Die God Laughs" (Cobb, 2006; Sayeed, 2006) are vivid and memorable, but the view that homosexuality is evil is not limited to such spectacular displays.

Among religions that posit homosexuality as sinful, most advocate love and forgiveness. For instance, the conservative Church of the Nazarene describes "loveless judgmentalism" as being as undesirable as "unconditional approval" (Church of the Nazarene, n.d.). In everyday practice, however, a great deal of such "loveless judgmentalism" does arise. In such situations, people who are known (or thought) to have even same-sex desires are expelled from the community, in effect being treated as if their desires contitute them as evil once and for all. For example, Wolkomir (2006) cites the story of a 
young woman who confessed her same-sex attractions to her pastor, who the next week declared to the congregation that one of the "demonic" was in their midst and made it clear that it was she; when she went home, she found herself locked out of the house and her belongings piled in the driveway (pp. 3-4). Likewise, in a discussion of an Atlanta gay bar's weekly Christian gospel music show, Gray and Thumma (1997) quote numerous gay Christians who grew up believing they were "hated by God" (p. 91). These respondents' friends, family, and churches act in such as way as to suggest that people who express any same-sex sexual desire are evil and taint the religious community if they are allowed to remain. Among Orthodox Jews, one of Shokeid's (1994) respondents called the National Council of Young Israel requesting their policy statement on homosexuality and was told, "I don't want to waste a minute on that. There is a passuk [verse] in the Torah: it is an abomination!" When another respondent came out to his father, the latter replied, "It is better to die than live the life of a homosexual!" (pp. 19, 71).

Such attitudes make it difficult or downright unbearable for members who have same-sex attractions. Approximately 50\% of Barton's (2010) informants "reported enduring long-term psychological distress associated with their fears that being gay was unacceptable in the eyes of god and society," and over $75 \%$ of her gay and lesbian respondents "suffered anxiety, fear, depression, or suicidal thoughts because, in their social circles, to be homosexual was to be a sinful outsider" (pp. 473, 475).

\section{"Love the Sinner, Hate the Sin"}

The second view in my typology does not condemn gay and lesbian members as individuals, but still posits same-sex sexual behavior as sinful. Casting people out for sexual transgression may have fairly old roots in some religious communities. But around the 1950s, some Christians began to state that this practice was unchristian, given that Christianity claims embracing everyone as its goal (White 2008, p. 105). By the 1970s, gay and lesbian Christian and Jewish congregations existed and gay men and lesbians were a visible presence in some more traditional religious communities (Comstock, 1996; Cooper, 1989; Shokeid, 1994; Warner, 1995; Wilcox, 2003), along with some of the theological arguments for the acceptance of homosexuality (Stuart, 2003). In response, some permission has been granted for this version to appear in e-Publications@Marquette. Taylor \& Francis (Routledge) does not grant permission for this article to be further copied/distributed or hosted elsewhere without the express permission from Taylor \& Francis (Routledge). 
Christians and Jews who believed that homosexuality was not God's ideal nonetheless began to articulate publicly the flaws in the reasoning (or lack thereof) behind religious institutional hostility, leading to a less condemnatory but still homonegative view.

In direct response to those who shut lesbians and gay men out of the church, many Protestants explicitly state that human beings are all sinners and God does not hate anyone while they maintain that same-sex sexual behavior is nevertheless sinful so people should choose to resist temptation. A Protestant theologian, Stackhouse (1998) posits that Protestants believe that "all are sinners in need of the grace of God," so no one should "cast stones" at homosexuals. For him, the Scriptural prohibition and the lack of procreative capacity render same-sex sexual relationships less-than-ideal. Still, he says, "Pastoral care for adults who are single, gay, unable to procreate, or divorced is seen as morally and spiritually required, even if their situations are not approved" (pp. 128, 120).

This principle of loving the sinner and hating the sin is widespread, but there are variations within it when it comes to the question of the origin of homosexuality. These variations are particularly significant because this view is so often cast as positing homosexuality as "chosen." Among the views that welcome homosexuals as sinners, we can distinguish three approaches. Some see same-sex sexual behavior as a sinful choice equally tempting to all. Others see the desire for such behavior as caused by a dysfunction or pathology in particular individuals' lives. A third group sees homosexuality as an inherent disposition in some people that is not itself sinful, but that can present the temptation for sinful behavior.

The first variation echoes the psychoanalytic claim that human beings are all born with polymorphous desires and a disposition to any object choice. While Freud saw variation as natural and potentially healthy, proponents of this view believe that it is contrary to God's plan and thus all human beings are obligated to suppress sinful desires, including sinful sexual desires, and refrain from proscribed behaviors. For example, I interviewed a man I call Mark, who suggested he held this view when he said: 
I guess what I'm getting at is that ... um... I honestly do believe homosexuality is more a matter of choice.... I think the thing that I said about alcoholism is a good example. Everyone says that it's genetic. But it doesn't mean if you're genetically predisposed to be an alcoholic that you'll end up ruining your life drinking. [...] Just because you're genetically predisposed to be one way or the other doesn't mean that you don't have [volition]... you have your work, you're a person... you can decide, to do what you want to do, right? I think there's something really losing if you don't believe that about people, otherwise we're all just sort of robots (Moon, 2004, p. 68).

When I asked him about people I had spoken to who believed that they had no choice about being heterosexual, he responded, "I think that's a lie. I mean, everybody is attracted to one degree or another to men and women" (p. 68). In this respondent's understanding, everyone has the potential to be tempted in any variety of ways; we must all resist temptations so as to maintain what he considered "social order."

While some focus on same-sex sexual behavior as a sinful choice that can tempt anybody, a second variant in this category posits same-sex sexual desire as being rooted in a pathology caused by abuse or childhood dysfunction and thus susceptible to "treatment." Dallas (1991), Nicholosi (1994), and Lamm (1978), for instance, see same-sex desires rooted in such childhood dynamics as feeling neglected by a father or dominated by an overbearing mother, though Jenkins (2010) reports that research "has not provided consistent evidence to support this hypothesis" (p. 285). Responding to the borngay argument that posits sexual orientation as innate, proponents of this view often make an analogy between homosexuality and alcoholism, as we saw in Mark's comments above. In this view, the innateness of a disposition does not justify the behavior or condition.

Until recently, the "ex-gay" movement clearly fit into this category; indeed, Dallas was a leader in that movement for many years, and its proponents often cite Nicholosi's publications. According to this movement, the religious community should welcome LGBT people as friends, helping them to repent of their same-sex sexual behaviors and avoid them in the future (Erzen, 2006; Gerber, 2009). It offers therapeutic help in the form of support groups and more 
formal programs to help them to overcome their less-than-ideal identities and possibly even the feelings that led them to identify with them in the first place. viii Scholars have found in ex-gay therapeutic programs that forbidden sexual behavior may be forgivable, while gay identity is grounds for immediate expulsion (Erzen, 2006).

Similarly, some Orthodox Jews view homosexuality as caused by an illness rather than a willful rejection of God's laws. Citing Lamm (1978), Unterman (1995) writes:

The most sympathetic Orthodox response to homosexuality is also the one least acceptable to large sections of the gay community.... Homosexual preference and practice are to be viewed as symptoms of a sickness, whether psychological or physical in nature. Gays, although they should not have samesex relations, may not be entirely responsible for their actions because they are subject to a form of compulsion. ....Gay Jews, according to this approach, should be encouraged to seek treatment for their condition and ultimately return to the fold as heterosexuals ( $p .73$ ).

Whether proponents of this perspective see homosexuality as an illness or a struggle God gives a person to deal with, they do not see homoerotic desires or activities alone as cause for expulsion. While life within the religious community may be inhospitable to gay men and lesbians, they are still not expected to leave it, and are supposed to be as welcome as any other member. As Rabbi Meir Fund (Dubowski, 2001) states:

We never heard that a Jew is barred from a shul [synagogue] because he is a sinner. If that was the policy of the halakha [Jewish law], then I hate to tell you I doubt there'd be a minyan [prayer quorum] in any shul $(1: 16: 34)$.

As Shokeid (1995) observed, however, a member who reveals his (or her) homosexuality may be denied the honors given to other members within the community.

Some see same-sex sexual behavior as a temptation for everyone, and others see it as an illness or dysfunction only some must deal with. In contrast to both perspectives, the Roman Catholic Church (joined by some evangelical Protestants) offers a third view, 
explicitly positing homosexuality as a fixed disposition in some people, while still seeing same-sex sexual behavior as sinful and avoidable. The National Conference of Catholic Bishops (1997) has stated that gay men and lesbians should be loved rather than shunned, and that same-sex sexual behavior is no more sinful than any non-marital sexual behavior. Addressing the "choice" questions, the bishops recognize that, "Generally, homosexual orientation is experienced as a given, not as something freely chosen" and see the orientation itself as therefore not sinful (p. 6). Their position on sexual behavior likewise tries to equate homosexual and heterosexual persons, suggesting that everyone, regardless of sexual orientation, is called to value and respect "her or his own dignity and that of others" in relationships, loving without "selfishness and aggression." This may seem to allow for same-sex sexual relationships that value and respect the dignity of oneself and others, except that the Catholic Church sees same-sex sexual behavior as sinful. ${ }^{\text {ix }}$

Similarly, in 2012 Alan Chambers, then-president of the ex-gay organization Exodus, announced that the organization would stop claiming to "change" people's sexual orientation stating that "99.9 percent of [Exodus participants] have not experienced a change in their orientation" and pulling books on reparative therapy from the Exodus bookstore. He elaborated his position in an interview (Gritz, 2012), stating:

We have a conviction that same-sex sexual expression is incompatible with a healthy Christian sexual ethic. It's not that we don't have attractions. It's just that we have a priority higher than our sexual orientation (n.p.).

A year and a half later, he disbanded the organization, seeing it as having become judgmental and "short on grace." Like everyone whose views fit into this category, he continued to see celibacy as the only valid alternative to heterosexual marriage.

The "Love the Sinner, Hate the Sin" view addresses the hostility often present in the more extreme homonegative view, and dispenses with the notion that homosexuality is worse than any other sin. Some go so far as to say that homonegative religious institutions have sinned with regard to LGBT people; Chambers (Gritz, 2012), for instance, remarked: permission has been granted for this version to appear in e-Publications@Marquette. Taylor \& Francis (Routledge) does not grant permission for this article to be further copied/distributed or hosted elsewhere without the express permission from Taylor \& Francis (Routledge). 
It's really the fault of the church that we have, as Christians, ever caused people to doubt the fact that Christ loves all of us the same. That's something we absolutely have to correct (n.p.).

Rather than branding homosexuals and purging them from the community, people with this perspective try to welcome them and espouse equality. They sometimes falter; for those who experience their same-sex attractions as immutable, insisting on lifelong celibacy for all lesbians and gay men, but only heterosexuals who feel called to it, can feel like an unjust burden (Gerber, 2011, p. 42), and insisting on change or celibacy without support can, as noted above, cause emotional trauma (Lee, 2012).

\section{MODERATE Views}

Two views fall into the middle of this typology. The first of these moderate views is more homonegative and the second is more homopositive.

\section{"We Don't Talk About That"}

The third view is more of a non-view: "We don't talk about that." Because homosexuality is not discussed, this view connects to no particular perspective on the fluidity or fixity of sexuality. This is not a homopositive approach, but it can have both positive and negative aspects. On the positive side, there can be a freedom that comes with invisibility-a freedom from surveillance, from having to accommodate oneself and one's life to others' categories and perceptions (Foucault, 1978). Ethnographic researchers in the U.S. point to the possibility of compartmentalizing sexuality and religious to avoid cognitive dissonance. On the negative side, researchers and others show that silence can allow homonegative hostility to flourish, silence LGBT people and allies, and foster destructive feelings in LGBT people themselves.

In the U.S. today, there does not seem to be much evidence of silence about homosexuality having positive effects, possibly due to the deeply entrenched homonegative and heteronormative assumptions that govern much of our society. Of course, it is possible that enjoying invisibility by definition makes explicit statements about its positive effects hard to come by. 
Researchers have, however, found examples of gay individuals appreciating membership in homonegative religious communities where they are not required to foreground their sexual orientation. Pitt (2010) discusses some non-negative experiences of this approach in his study of how gay, Black members of homonegative churches deal with the conflict that emerges from being equally committed to their gay identities and their homonegative churches. In these settings, some of the men found it possible to "compartmentalize," or to isolate their gayness from their religion. He quotes a respondent named Wayne, the coordinator of his church's security team, who remarked:

I mean, honestly, I don't mix my sexuality with my religion. When I go to church, I'm not really there as a homosexual. I mean, that's not why I'm there. I'm there to praise the Lord and to hear a word. I'm not really thinking of the sexuality part even though it may come up in a sermon or something (p. 48).

Likewise in a Jewish context, a member of the gay synagogue Shokeid (1994) studied left to join an Orthodox synagogue and remarked: "It is my community; I pray with them; we talk and gossip together. True, I am somewhat peculiar because I am not married, but I don't advertise my sexual identity" (p. 147). Shokeid found that other gay Orthodox men participated in non-gay synagogues as well, where their sexual orientation was often kept an open secret.

While members who are not highly involved in religious discussions in their organizations might find it relatively easy to compartmentalize, it is more difficult for others. Rashawn, a seminarytrained Sunday school teacher in Pitt's (2010) study remarked:

For example, how do I teach from Romans 1 without dealing with homosexuality? Even if I try to sidetrack it, somebody in the class always asks about it. I really cringe... because it is my job there to teach what the church believes and not what I believe (p. 48).

Furthermore, compartmentalization would require a man's romantic relationship to be with a man who was not religious, which was not desirable for some respondents (p. 48).

Belonging, perhaps marginally, to a group that rejects a major component of one's identity seems an ambivalent situation at best, permission has been granted for this version to appear in e-Publications@Marquette. Taylor \& Francis (Routledge) does not grant permission for this article to be further copied/distributed or hosted elsewhere without the express permission from Taylor \& Francis (Routledge). 
and the negative effects of silencing discussion of homosexuality in the U.S. have been explicitly documented. These include internalizing homonegative views and feeling isolated and fearful. In Love's (1998) study of LGB life at a Catholic college, the silence around lesbian, bisexual, and gay issues allowed cultural tropes of homophobia and heterosexism to flourish, fostered anti-gay hostility, silenced pro-gay voices, and left gay and lesbian students feeling isolated and vulnerable (p. 298). A lesbian student told Love (1997):

When I first arrived here there was no mention of words, like gay, lesbian, etc. I felt isolated.... The total mindset was "this does not exist here." I heard no mention of it from anybody.... If you don't hear it from anybody else, you can't ever get a feel for who's going to support you and who wouldn't.... It made me very closed.... I could not put that much emotional attachment into somebody who I was afraid was going to turn around and reject me (p. 386).

As Love reflects:

The institution was perceived as being focused on service to others, spirituality, caring for the individual, and educating the whole student, yet lesbian, gay, and bisexual students experienced hatred, pain, loneliness, anger, helplessness, rejection, and isolation in that setting (p. 386).

Writing from a Jewish perspective, Wahba (1989) similarly focuses on the effects invisibility has one one's relationships and one's soul. She compares invisibility as a lesbian to the forced invisibility her family needed to protect themselves from anti-Jewish rioters in Iraq in 1941, writing:

Particularly with people I feel an affinity with... it is distressing to exclude and censor out important aspects of my life, thing things other people talk about freely, specifically in regard to my mate.... Coming out has to be better for the soul than passing through life in various shades of invisibility. It can be uncomfortable and even frightening at times. But not to do so leaves us disconnected, somehow (pp. 54, 56).

Some suggest that such invisibility and separation from others can lead LGBT people to internalize society's hostility, as Shokeid 
found of gay men in Orthodox congregations. In Love's (1997) study, this "climate of fear" seemed linked to suicidality (p. 387). The evidence suggests that in U.S. institutions, a culture of silence has more negative effects than positive because of the broader heterosexist and homonegative messages in our society.

"They Can't Help It"

The second moderate view is more favorable to homosexuality, as it is often expressed by those who wish to welcome and accept LGBT people. It espouses tolerance, arguing that gay people "cannot help it," so they should not face discrimination (Haider-Markel \& Joslyn, 2008). Furthermore, those espousing this view often argue that being LGBT is so painful, no one would choose it if they could. It thus depends on sexual fixity to render homosexuality acceptable.

We see this view expressed in Umansky's (1997) analysis of Jewish thought:

[A] Ithough the Bible views homosexual behavior as a freely chosen course of action, modern research indicates that men and women do not choose to be homosexuals. Indeed, one might ask, in a homophobic society such as ours, why would one deliberately choose a sexual lifestyle that often brings with it the constant fear of discovery, job loss, family estrangement, ridicule, and harassment (p. 186)?

Among Protestants, Britta Reitan, the sister of a young gay man interviewed in a documentary about Christians and homosexuality, reflected on their parents' earliest attempts to deal with their son's being gay (Karslake, 2007). A friend had suggested that if they did not support him, he would be discouraged and change his sexual orientation. Reitan recalled:

[My mom] thought maybe he wasn't really gay, and could change, but I obviously disagreed. Seeing the pain he had gone through the year before, if he wasn't really gay, there was no reason to endure that $(1: 00: 03)$.

In this view, the fact that gay men and lesbians, and possibly transgendered people (bisexuals are generally missing from these arguments, for reasons that will become clear) experience so much pain proves that they cannot help but be that way. permission has been granted for this version to appear in e-Publications@Marquette. Taylor \& Francis (Routledge) does not grant permission for this article to be further copied/distributed or hosted elsewhere without the express permission from Taylor \& Francis (Routledge). 
This analysis often helps people to move from a position decrying homosexuality to welcoming gay men and lesbians into their communities, by casting gay men and lesbians as "blameless" (HaiderMarkel \& Joslyn, 2008). Although much social scientific research establishes that the sexual categories we recognize in the United States today are not timeless, universal realities (for example, Abelove, Barale \& Halperin, 1993; Comstock \& Henking, 1997; FaustoSterling, 2000; Foucault, 1978), sociologists have found several reasons for the appeal of "essentialism," the understanding that sexual orientation is an "objective and transcultural fact" (Stuart 2003, p. 8). Warner (1995) remarks:

The power of gay Christian essentialism is that it (1) invokes a powerful and benevolent God to proclaim the issue of homosexuality to be beyond human control...; (2) frees parents from doubt; (3) denies that homosexuality is in any way contagious; (4) expresses solidarity with grass roots gay culture; and (5) demands, as a matter of simple justice, inclusion of gays as simply another tile in the American mosaic (p. 99).

Wilcox (2003) adds that the essentialist, "born gay" argument is politically expedient, removes guilt, directly challenges homonegative religious arguments that demonize LGBT people with the language of choice, and speaks to the feelings of constraint rather than choice that many LGBT Christians (and clearly others as well) experience, particularly if they come from backgrounds where it is harshly stigmatized.

In spite of its popularity, however, as an attempt to argue for the inclusion of LGBT people, this argument is beset by weaknesses. First, this view depends on the supposed innateness of homosexuality to make it acceptable, implying that it would be wrong for anyone who would rate a 0-5 on the Kinsey scale to "choose" to fall in love with someone of the same sex. In addition to insisting that bisexuals live as heterosexuals, this view also implies that consciously choosing to identify as gay or lesbian is not a positive choice for "Kinsey sixes" either. Second, as we saw above, rather than directly address the "hate the sin" argument, arguing that "they can't help it" casts samesex sexual activity as a compulsion. In addition, proponents can seem to dodge the moral question, using science disingenuously to permission has been granted for this version to appear in e-Publications@Marquette. Taylor \& Francis (Routledge) does not grant permission for this article to be further copied/distributed or hosted elsewhere without the express permission from Taylor \& Francis (Routledge). 
rationalize their pro-gay bias. Those who see homosexuality as sinful or unhealthy can furthermore argue that it is not doing anyone a kindness to encourage them to act on a desire simply because it "feels natural" to them (Stackhouse 1998, p. 128). Finally, this argument can make gay and lesbian pain the price of admission to the community. If pain is the reason to welcome LGBT people into the community, then LGBT people who are not particularly pained may seem not to belong (Moon, 2005b).

\section{Homopositive views}

In addition to believing that it is wrong to shut people out of the community of faith, people with homopositive views believe that homosexuality can be a good thing. Proponents of both of these views see the six scriptural passages commonly used to prohibit homosexuality as needing to be understood in their historical context and irrelevant to contemporary, egalitarian, committed same-sex relationships. They also see homonegative interpretations of scripture as oversimplifications that justify contemporary prejudice. ${ }^{x}$ They see God's chief principle as infinite love, creativity, and community. While others have drawn other distinctions (Cheng, 2011; Cornwall, 2011; Loughlin, 2007; Stuart, 2003), I distinguish the two views in this category on the basis of how they characterize volition: the "God's Good Gift" view downplays any aspect of human choice with regard to sexual identity, while the "Godly Calling" view posits (or at least allows) sexual and gender variation to be positive choices a person can make to move closer to God. The latter view is thus more able to embrace sexual and gender fluidity.

\section{"God's Good Gift"}

The fifth view can share the "born gay" assumptions of the "They Can't Help It" perspective but destigmatizes lesbian and gay identities by positing them as intentionally created by God and deemed good. Proponents of this perspective argue that God makes some people lesbian or gay, though there are differences and subtleties with respect to what that "making" means. They have elaborated the themes of understanding scripture in light of historical context and seeing homonegativity as a human failing rather than a godly mandate. Within this perspective, people stress that sexual orientation is a part of God's creation beyond personal volition, while the choice to 
behave morally or immorally is one all individuals must make. Furthermore, some argue that taking the full diversity of creation seriously, including the experiences of lesbians and gay men, can give everyone, including heterosexuals, new insights into the nature of God, love, and creation.

People taking this position often posit one's sexual orientation as "natural" and God-given (Lee, 2012; Love, 1997, 1998; Pitt, 2010; Rogers, 2009; Solomon, 1995; Spong, 2004; Thumma, 1991; Warner, 1995; Wilcox, 2003). Reflecting the more biologistic version of this argument, a heterosexual Methodist named Ruthie clearly described homosexuality as part of God's good creation when I interviewed her (Moon, 2004). Ruthie said:

I believe that it [sexual orientation] is a biological design, I do not believe that it is a social condition or that it is a lifestyle choice. As many of my friends say it is not a lifestyle, it is a life. I believe we are, to use a contemporary image, but I truly believe it, that we are a rainbow of God's creation. [...] And I think that when we deny that we are denying God's genius of creation. I think we're about to learn more. As our own technology moves forward, we'll be able to describe the foundation of how we are who we are, because some of our gifts really do come with us (p. 103).

Less biologically-oriented, in a survey of the gay and lesbian Catholic organization Dignity, Dillon (1999) found that members experienced their sexuality as coming from God. She summarized:

[T] he view reiterated by Dignity survey respondents was that sexuality was natural, innate, and divinely prescribed, and that differences in sexuality did not detract from individual integrity or relational wholeness. Importantly, Dignity participants' essentialist interpretation of their sexuality was not located simply in a biological identity but in what they see as a Godgiven sexuality.... In short, in the experience of the gay and lesbian participants in Dignity, "if you're gay," as one respondent phrased it, "you're gay as a creation of God. There is no choice involved" (pp. 125-126). ${ }^{\text {xi }}$

Dillon points out that to see homosexuality as a creation of God does not necessarily mean one has to see a biological root to it. 
Likewise, writing from a Jewish perspective, Solomon (1995) responds to those who see gay men and lesbians as evading their ethical obligation to marry and procreate, remarking on the ambiguity of what it means to be God's "creation," he states:

It is my deeply held belief, shared by many lesbians and gay men, that this homosexual nature was implanted in me by my Creator. The purpose and precise means of this are open to endless speculation, but the fundamental conviction remains that God created me, and wills me to be, gay (p. 81).

Some define LGBT identity as a gift from God. Wilcox (2003) remarks, " $[T]$ he imagery of God becomes even more important.... the additional claim that it is a sacred gift makes LGBT identity something not just to be endured but to be celebrated" (p. 71). Similarly, addressing both the "They Can't Help It" and "Love the Sinner, Hate the Sin" arguments directly, Pastor Cordelia Strandskov (2011) published a sermon where she remarked:

How often do we hear people talk about homosexuality as something that is "not a choice," as if it would be the wrong choice? ... I'm here to let you in on a secret: Being a lesbian is a wonderful thing, and I wouldn't change it if I could. I have always felt like being gay was a blessing. God made me this way and I am SO grateful! When discussions about gay rights in government and churches focus on the argument that we have no choice, they completely disregard the fact that we are whole, beautiful, blessed people. Those arguments serve to keep us in a state of victimhood, to make us feel like equal rights and opportunities would be benevolent gifts from people who were born better than us, rather than what we deserve as citizens and children of God. ...By marching in Pride, we are standing up to say that it's not about loving the sinner while hating the sin-it's about rejecting the idea that love is ever a $\operatorname{sin!}$ (n.p.).

These last two comments explicitly oppose the notion that homosexuality is in any way less than God's ideal; in these views, the lack of volition is not a sign of compulsion, because homosexuality is part of God's good creation, regardless of whether or not a biological root is ever found. Those that depend on biology may be subject to 
some of the same criticism of the last perspective. These latter views, on the other hand, answer the moral question by insisting that homosexuality is a blessing from God.

From this perspective, homonegative theology results not from a Godly mandate, but from humanity's limited, and sometimes bigoted, perspectives. From a Protestant perspective, Thumma (1991) sums up a similar, though more contextualist version of this interpretation in his discussion of a gay evangelical organization, saying:

Tension between sexuality and religiosity is understood as "an ungodly dualism between the body and the spirit." Problems resulting from a literal interpretation of scripture are redefined as issues of "cultural relativity." The choice then becomes either expressing one's God-given, unchangeable sexuality or being bound by "men's fears and opinions spoken in God's name" ( $p$. 340).

While most people with this perspective see scripture as true for the time in which it was written, Solomon (1995) goes farther, saying that the human beings who first committed it to writing were in error in this case. Responding to Leviticus 18:22, which is widely taken to forbid men to "lay with" other men, he says:

Such a prohibition, resulting in centuries of needless deaths and ruined lives, is utterly incompatible with the God whom I love and worship. Creation is the overflowing of divine love and goodness, and the divine image in which we are created impels us to love others created in the same image. This love reaches its highest intensity and meaning in a partnership involving sexual intimacy.... It would be contrary to the very nature of God and the rationale for creation to suppose that God makes women and men only to frustrate the realization of their human potential by a cruel and pointless command. The prohibition, then, is not Divine, but all too erringly human (pp. 81-82).

Others point to different harms that religious institutions cause by the "traditional" treatment of gay men and lesbians. For instance, in my own research (Moon 2004), a gay seminary intern named Cory saw other harms following from the distinction between being and practice, including separating people from God's and other people's 
love. Remarking on the United Methodist Church's ban on ordaining "self-avowed, practicing homosexuals," he said:

"Self-avowed, practicing": well, I am both. I think it's insane some of the ways people try to get around it, to deny themselves. We are sexual beings. I have seen [gay clergy] do a lot of different things to get around it; when they deny it, or try to, they're not experiencing the love they can. To be Christian is to be loving. I believe you can only lead people as far as you've gone. Some people can try to project what it would be, to be fully loving, but that's not it (p. 201).

From this perspective, to deny certain people sexual intimacy amounts to denying them the opportunity to love and be loved in all the ways God designed human beings to experience it.

Those espousing this view see homosexuality as created by God and deemed good, see religious institutions' homonegative stances as rooted in human bigotry or ignorance rather than God's truth, and point to the sin inherent in religious institutions' homonegative policies. Furthermore, they maintain that regardless of sexual orientation, human beings must all make ethical decisions-they simply didn't see sexual orientation as an ethical decision. Some of my own respondents echoed theologians Scanzoni and Mollenkott (1994), who compare homosexuality to left-handedness, arguing that even though both have been stigmatized, they are in fact morally neutral-bad or good things can be done with either hand, just as bad or good things can be done in the context of either sexual orientation. These proponents reject the assumption that same-sex sexual behavior is sinful in itself.

Coming from different religious contexts, these views articulate a strikingly similar theme: that listening to the experience of religious lesbians and gay men makes clear that sexual orientations are all created by God and give human beings insight into God's truths, particularly about love (Nugent, 1988). Some Christians (Goss, 1993; Jordan, 2000) see LGBT people as helping human beings better to understand God's message of solidarity with society's weakest, transcending oppressive, socially-created divisions, including those of sexuality and gender. 
To the extent that they assume that moral rightness depends on innateness or fixity, proponents of this view can be highly uncomfortable with the notions of sexual fluidity and volition over sexual identity, so bisexual and transgendered people, and anyone who has experienced change or volition with regard to their sexual desires, can fall by the wayside (Moon, 2005a). Given the continuum that sexuality researchers believe characterizes human sexuality, this argument potentially excludes or silences a significant proportion of the population. The final perspective has more room for sexual and gender fluidity, and it addresses some of the critiques that posit "born gay" arguments as denying free will.

\section{"Godly Calling"}

The "Godly Calling" view ${ }^{\mathrm{xi}}$, espoused largely by a subset of Protestant theologians, addresses the weaknesses of the "They Can't Help It" and "God's Good Gift" arguments by embracing volition. These views stress that same-sex sexual practices or transgenderism can be righteous choices, precisely because they help human beings better to understand how God's love breaks through human institutions (Althaus-Reid, 2000, 2003; Cheng, 2011; Stuart, 2003), as well as helping human beings to respond positively to a call from God to live the life God intends for them. These arguments comprise two common themes, that: (a) gender, sexuality, and marriage are flawed, human institutions (anchored by the philosophy of sexual essentialism) that God transcends, and (b) living in opposition to those institutionsincluding in passionate sexual expression that defies institutional rules-can reveal deeper truths about God's love and creation. Proponents of this perspective insist that same-sex sexual relationships, and transgenderism, can be the godly callings that move people "toward wholeness" (Tanis, 2003). In spite of the commonalties, these arguments are more rare and cohere less than other perspectives, perhaps because they are the newest, and perhaps because the "born gay" trope has been so dominant that alternative ways of being homopositive have become unthinkable for many.

Many queer theologians move beyond the "born-gay" argument by pointing to the social (and thus not divine) construction of gender and sexuality in general. Among queer theologians, it is common to accept the social constructionist view that contemporary sexual categories, the modern nuclear family form, and the contemporary permission has been granted for this version to appear in e-Publications@ Marquette. Taylor \& Francis (Routledge) does not grant permission for this article to be further copied/distributed or hosted elsewhere without the express permission from Taylor \& Francis (Routledge). 
meanings of maleness and femaleness, can be dated to the nineteenth century's parallel rises of capitalism and science in the West. From this perspective, the ideas that (a) "homosexual" and/or "heterosexual" are universal categories of human beings, and that (b) male and female are necessarily complementary halves, are historically contingent and thus humanly created. While those espousing a "Love the Sinner" argument also stress sexual fluidity and sexual ethics, Stuart (2003) and other queer theologians point out that heterosexuality is no less a modern construct than homosexuality, and see it as idolatrous to posit heterosexual marriage as uniquely Godly among sexual relationship forms (see also Rogers, 1998).

Some argue that these tenets have sometimes violently diverted the church from the more truly "queer" project of early Christianity, which disrupted bodily fixity and entrenched institutional patterns to reveal God's truth (Althaus-Reid, 2000, 2003; Cheng, 2011; Cornwall, 2011; Jordan, 2000, 2002; Loughlin, 2007; Stone, 2009; Stuart, 2003). Stuart (2003), for instance, argues that "sexual and gender identities have to be subverted because they are constructed in the context of power and are part of a matrix of dominance and exclusion" (p. 108). Rogers (2011) echoes that view in his discussion of samesex marriage, when he writes that the purposes of marriage is to give people an experience analogous to God's love. Referring to the phrase in Galatians (3:28) that "In Christ there is no 'male and female,'" and arguing that God and Jesus transcend gender, he writes:

"No 'male and female'" also reminded the early church of the examples of Jesus and Paul. They both kept mixed company without needing completion by someone of the opposite sex. Their recorded words never connected marriage with procreation. Jesus was born from a woman alone (as God made Eve from a man alone). The early church used such examples to defend Christianity's most shocking departure from Late Antique morals-the founding of monasteries.... Because the body of the medieval Christ both retains his circumcision and gains a womb, Christ resembles an intersex person. Because the body of Christ is male in the history of Jesus and female in the history of the church, Christ resembles a transsexual person. Because Christ can be the bridegroom to a male believer, he resembles the 
same-sex spouse. Gender does not limit Christ, because he is its Lord (n.p.).

Rogers keeps his thinking open to sexual and gender fluidity by insisting that God, and God's love, transcend simple notions of malefemale complementarity. For Rogers (1998), same-sex relationships are chosen despite social mandates much as God loves each person as an active choice rather than thoughtless habit. Thus, the former teach people about God's infinite scope and love, and it follows that the choice to live as gay, lesbian, or bisexual can be a righteous one. One of Wilcox's (2003) respondents, Robert, made a similar claim when he stated:

I can choose...emotionally and physiologically, to be attracted to women. That's not what my heart is and ... that's not my life.... I guess what I'm trying to say is we can... change our behaviorwe cannot change our orientation (p. 69).

Writing from a transgender perspective, Tanis (2003) makes this most explicit theological argument that living in a non-traditional way can be a Godly calling, a choice to follow the path God has laid out for oneself. He writes:

I believe for a number of reasons that the lens of calling is a useful and relevant way to look at gender.... Rather than simply being a fluke, an oddity, or a source of shame, gender variance comes to be seen as part of our God-given identities. Even more than that, it becomes our spiritual responsibility to explore fully the nature that God has given to us. Like a calling, our sense of our own genders arises from within us and, at the same time, seems to come from a source that is beyond our control and volition (p. 149).

His argument that transgendered life is a Godly calling could be extended to sexual orientation as well. Being gay, lesbian, or bisexual may be looked at positively, as a spiritual responsibility to fulfill; for many, sexual orientation can seem to arise "from within us and, at the same, time, [...] to come from a source that is beyond our control and volition." For Tanis, "If it comes from God, then the calling moves us toward wholeness and a sense of our own life's purpose" (p. 158). Similarly, in a critique of the Vatican's 1986 Letter to the Bishops, Nugent (1988) stressed the importance of listening to gay men and 
lesbians when they speak of their experiences and feeling of "rightness" in their sexuality, something many others call for as well. Extending these arguments, feeling a greater sense of wholeness or "rightness" is the confirmation a gay, lesbian, transgender, or bisexual Christian would look for to know she or he was living in harmony with God's plan, or had made the right choice.

From this perspective, the "cause" of homosexuality is irrelevant; all sexuality is human and thus imperfect, yet a possible aid to redemption. If same-sex sexuality and/or LGBT and queer cultures help to break through social categories and institutions, then they are allowing God's message to be heard. This argument does not depend on science, nor does it depend on positing everyone's sexual orientation as fixed-two weak empirical foundations-to establish the moral worth of being lesbian or gay. It also has room for bisexuals, transgendered people, and other "queers" whose sense of themselves does not conform to the narrative of sexual fixity. It establishes the morality of sexual and gender fluidity or volition. It asserts that the choice to experience intimacy with another, of whatever sex, and to experience embodiment through gender transformation, can be ways of (a) obeying God; (b) learning more about the infinite nature of God, love and creation; and (c) choosing to follow God in spite of the heavy weight of human institutional demands. At the same time, proponents of this view address the feeling many LGBT people have that their sense of themselves is both beyond volition and something they can choose to embrace, without pathologizing homosexuality as a "compulsion."

As personally powerful as they may be, individuals' feelings of "rightness" make a shaky debate platform. The past twenty years have clearly shown that "born gay" arguments work to make allies for LGBT persons (Haider-Markel \& Joslyn, 2008), even though they also fuel endlessly circular arguments with detractors. However, as Stuart (2003) points out, much gay theology (what I call "God's Good Gift" views) has been unable to move past its deadlock with heterosexist theology. For her, queer theology's rejection of human identity categories shows the way beyond the stalemate. 
NOT THE PUBLISHED VERSION; this is the author's final, peer-reviewed manuscript. The published version may be accessed by following the link in the citation at the bottom of the page.

\section{Conclusion}

By acknowledging the wide range of religious views of homosexuality, it is my hope that debates about these topics may be more productive and informed. I hope this discussion will inspire readers to seek to understand the intricacies of religious perspectives on homosexuality both in faith communities and as they influence public discourse. Religious perspectives offer a great deal more nuance than the "born gay"/"sinful choice" dichotomy allows. Disrupting this dichotomy helps us to dispel the pernicious myth that "born gay" views are necessarily homopositive and that concepts of sexual fluidity or volition are inherently antigay. It also reveals commonalties in views that might seem on the surface to be completely opposed. The "God Hates Fags," "They Can't Help It," and "God's Good Gift" views, and the third variant of "Love the Sinner"-as intensely as their proponents would disagree among themselves-share the assumption of sexual fixity. While they differ in how they define sexual righteousness, most "Love the Sinner" iterations share with the "Godly Calling" view the assumption that moral choice is relevant to the questions of sexual identity and practice. The "God's Good Gift" view shares with both of these the claim that religious institutions and communities themselves have things to repent of with regard to their treatment of LGBT people. At the core of the disagreement lies the fundamental question of whether same-sex sexual activity necessarily distances people from God, or can bring people closer to God.

The themes of innateness and choice, fixity and fluidity, righteousness and sin tend to constellate into some clusters, but there is nothing inevitable or universal about those clusters. Breaking apart the clusters may let more light into religious and secular conversations about homosexuality. In particular, those invested in arguments that attach rights to biology should take care with this strategy, as it may not always help them to achieve their goals. Even if a "gay gene" were one day to be isolated, human beings would still be shaped in the course of childhood development and by the options made available in their particular societies. Furthermore, simply having a genetic root does not establish the moral correctness of any trait, as we have seen; indeed, the eugenic efforts of the nineteenth and twentieth centuries should give pause to anyone staking their hope for LGBTQ freedom, equality, or inclusion on biology. Although the "born gay" argument 
has helped to secure many gains for the LGBT movement in religious and secular policies, it might not be the most liberating approach in the long run, since it forecloses sexual fluidity and the possibility that sexual or gender nonconformity could be a morally good choice.

Many people of faith-regardless of their view about the moral value of homosexuality-stress that religions' overall message is to treat others with love and compassion. Showing love and compassion might include taking people seriously and listening to them as they relate their experiences of love, desire, and faith. Creating more understanding can change some minds, but it need not change minds to have positive effects. Indeed, honest and respectful dialogue can solidify people in their beliefs, while also increasing their respect for each other and deescalating conflict (Fowler, Gamble, Hogan, Kogut, McComish, \& Thorp, 2001). Mutual understanding, on all sides, may lead to less unproductive bickering, less harm, and more humane policies and practices throughout society.

\section{References}

1. Abelove, H., Barale, M. A., \& Halperin, D. M. (1993). The lesbian and gay studies reader. New York, NY: Routledge.

2. Althaus-Reid, M. (2000). Indecent theology: Theological perversions in sex, gender and politics. New York, NY: Routledge.

3. Althaus-Reid, M. (2003). The queer God. New York, NY: Routledge.

4. Barton, B. (2010). "Abomination": Life as a Bible Belt gay. Journal of Homosexuality, 57, 465-484.

5. Barton, B. (2012). Pray the gay away: The extraordinary lives of Bible Belt gays. New York, NY: NYU Press.

6. Bell, A. P., \& Weinberg, M. S. (1978). Homosexualities: A study of diversity among men and women. New York, NY: Simon and Schuster.

7. Blumstein, P. W., \& Schwartz, P. (2000). Bisexuality: Some social psychological issues. In P. C. Rodriguez-Rust (Ed.), Bisexuality in the United States: A social science reader (pp. 339-351). New York, NY: Columbia University Press.

Journal of Homosexuality, Vol. 61, No. 9 (2014): pg. 1215-1241. DOI. This article is (C) Taylor \& Francis (Routledge) and permission has been granted for this version to appear in e-Publications@Marquette. Taylor \& Francis (Routledge) does not grant permission for this article to be further copied/distributed or hosted elsewhere without the express permission from Taylor \& Francis (Routledge). 
NOT THE PUBLISHED VERSION; this is the author's final, peer-reviewed manuscript. The published version may be accessed by following the link in the citation at the bottom of the page.

8. Boswell, J. (1980). Christianity, social tolerance and homosexuality: Gay people in Western Europe from the beginning of the Christian Era to the fourteenth century. Chicago, IL: University of Chicago Press.

9. Cheng, P. S. (2011). Radical love: An introduction to queer theology. New York, NY: Seabury Books.

10. Church of the Nazarene, Board of General Superintendents. (n.d.). Pastoral perspectives on homosexuality. Kansas City, MO: Church of the Nazarene. Retrieved from Nazarene.org/files/docs/Perspectives_Homosexuality.pdf

11. Cobb, M. (2006). God hates fags: The rhetorics of religious violence. New York, NY: New York University Press.

12. Comstock, G. D. (1996). Unrepentant, self-affirming, practicing: Lesbian/bisexual/gay people within organized religion. New York, NY: Continuum.

13. Comstock, G. D., \& Henking, S. E. (Eds.). (1997). Que(e)rying religion: A critical anthology. New York, NY: Continuum.

14. Cooper, A. (1989). No longer invisible: Gay and lesbian Jews build a movement. Journal of Homosexuality, 18, 83-94.

15. Cornwall, S. (2011). Controversies in queer theology. London, England: SCM Press.

16. Dallas, J. (1991). Desires in conflict: Answering the struggle for sexual identity. Eugene, OR: Harvest House Publishers.

17. De Cecco, J. P., \& Parker, D. A. (1995). The biology of homosexuality: Sexual orientation or sexual preference? Journal of Homosexuality, 28, $1-27$.

18. Dillon, M. (1999). Catholic identity: Balancing reason, faith and power. New York, NY: Cambridge University Press.

Journal of Homosexuality, Vol. 61, No. 9 (2014): pg. 1215-1241. DOI. This article is @ Taylor \& Francis (Routledge) and permission has been granted for this version to appear in e-Publications@Marquette. Taylor \& Francis (Routledge) does not grant permission for this article to be further copied/distributed or hosted elsewhere without the express permission from Taylor \& Francis (Routledge). 
NOT THE PUBLISHED VERSION; this is the author's final, peer-reviewed manuscript. The published version may be accessed by following the link in the citation at the bottom of the page.

19. DiMaggio, P., Evans, J., \& Bryson, B. (1996). Have Americans' social attitudes become more polarized? American Journal of Sociology, 102, $690-755$.

20. Dubowski, S. S. (Director and Producer), \& Smolowitz, M. (Producer). (2001). Trembling before $G-d$ [Documentary]. United States: New Yorker Films.

21. Erzen, T. (2006). Straight to Jesus: Sexual and Christian conversions in the ex-gay movement. Berkeley, CA: University of California Press.

22. Farley, M. A. (1998). Response to James Hanigan and Charles Curran. In S. M. Olyan \& M. C. Nussbaum (Eds.), Sexual orientation and human rights in American religious discourse (pp. 101-109). New York, NY: Oxford University Press.

23. Fausto-Sterling, A. (2000). Sexing the body: Gender politics and the construction of sexuality. New York, NY: Basic Books.

24. Foucault, M. (1978). The history of sexuality, volume I: An introduction. New York, NY: Vintage Books.

25. Fowler, A., Gamble, N. N., Hogan, F. X., Kogut, M., McComish, M., \& Thorp, B. (2001, January 28). Talking with the enemy. Boston Globe. Retrieved from pubpages.unh.edu/ ${ }^{j}$ ds/BostonGlobe.htm

26. Freud, S. (2000 [1905]). Three essays on the theory of sexuality. Trans. James Strachey. New York, NY: Basic Books.

27. Gerber, L. (2009). From gays to men: Godly masculinity in ex-gay ministries. Paper presented at the annual meeting of the Association for the Sociology of Religion, San Francisco, CA.

28. Gerber, L. (2011). Seeking the straight and narrow: Weight loss and sexual reorientation in evangelical America. Chicago, IL: University of Chicago Press.

29. Goss, R. (1993). Jesus acted up: A gay and lesbian manifesto. New York, NY: Harper Collins.

Journal of Homosexuality, Vol. 61, No. 9 (2014): pg. 1215-1241. DOI. This article is (C) Taylor \& Francis (Routledge) and permission has been granted for this version to appear in e-Publications@Marquette. Taylor \& Francis (Routledge) does not grant permission for this article to be further copied/distributed or hosted elsewhere without the express permission from Taylor \& Francis (Routledge). 
NOT THE PUBLISHED VERSION; this is the author's final, peer-reviewed manuscript. The published version may be accessed by following the link in the citation at the bottom of the page.

30. Gray, E. R., \& Thumma S. R. (1997). The Gospel Hour: Liminality, identity, and religion in a gay bar. In P. E. Becker \& N. L. Eieseland (Eds.), Contemporary American religion: An ethnographic reader (pp. 79-98). Walnut Creek, CA: Alta Mira Press.

31. Gritz, J. R. (2012). Sexual healing: Evangelicals update their message to gays. The Atlantic. Retrieved from http://www.theatlantic.com/national/archive/2012/06/sexual-healingevangelicals-update-their-message-to-gays/258713/

32. Haider-Markel, D. P., \& Joslyn, M. R. (2008). Beliefs about the origins of homosexuality and support for gay rights. Public Opinion Quarterly, 72(2), 291-310.

33. Jenkins, W. J. (2010). Can anyone tell my why I'm gay? What research suggests regarding the origins of sexual orientation. North American Journal of Psychology, 12, 279-296.

34. Jordan, M. (2000). The silence of Sodom: Homosexuality in modern Catholicism. Chicago, IL: University of Chicago Press.

35. Jordan, M. (2002). The ethics of sex. New York, NY: Blackwell Publishers.

36. Karslake, D. G. (Director and Producer). (2007). For the Bible tells me so [Documentary]. United States: VisionQuest Productions.

37. Kinsey, A. C., Pomeroy, W. B., \& Martin, C. E. (1948). Sexual behavior in the human male. Philadelphia, PA: Saunders.

38. Klein, F., Sepekoff, B., \& Wolf, T. J. (1985). Sexual orientation: A multivariable dynamic process. Journal of Homosexuality, 11, 35-49.

39. Lamm, N. (1978). Judaism and the modern attitude toward homosexuality. In M. M. Kellner (Ed.), Contemporary Jewish ethics (pp. 375-399). New York, NY: Sanhedrin Press.

40. Laumann, E. O., Gagnon, J. H., Michael, R. T., \& Michaels, S. (1994). The social organization of sexuality: Sexual practices in the United States. Chicago, IL: University of Chicago Press.

Journal of Homosexuality, Vol. 61, No. 9 (2014): pg. 1215-1241. DOI. This article is (C) Taylor \& Francis (Routledge) and permission has been granted for this version to appear in e-Publications@Marquette. Taylor \& Francis (Routledge) does not grant permission for this article to be further copied/distributed or hosted elsewhere without the express permission from Taylor \& Francis (Routledge). 
NOT THE PUBLISHED VERSION; this is the author's final, peer-reviewed manuscript. The published version may be accessed by following the link in the citation at the bottom of the page.

41. Lee, J. (2012). Torn: Rescuing the gospel from the gays-vs.-Christians debate. New York, NY: Jericho Books.

42. Loughlin, G. (Ed.). (2007). Queer theology: Rethinking the Western body. Malden, MA: Blackwell Publishing.

43. Love, P. G. (1997). Contradiction and paradox: Attempting to change the culture of sexual orientation at a small Catholic college. Review of Higher Education, 20(4), 381-398.

44. Love, P. G. (1998). Cultural barriers facing lesbian, gay, and bisexual students at a Catholic college. Journal of Higher Education, 69(3), 298-323.

45. Magonet, J. (Ed.). (1995). Jewish explorations of sexuality. Providence, RI: Berghahn Books.

46. Maher, M. J., Sever, L. M., \& Pichler, S. (2008). How Catholic college students think about homosexuality: The connection between authority and sexuality. Journal of Homosexuality, 55, 325-349.

47. McConkey, D. (2001). Whither Hunter's culture war? Shifts in evangelical morality, 1988-1998. Sociology of Religion, 62, 149-174.

48. Moon, D. (2004). God, sex \& politics: Homosexuality \& everyday theologies. Chicago, IL: University of Chicago Press.

49. Moon, D. (2005a). Discourse, interaction, and testimony: The making of selves in the U.S. Protestant dispute over homosexuality. Theory \& Society, 34, 551-577.

50. Moon, D. (2005b). Emotion language and social power: Homosexuality and narratives of pain in church. Qualitative Sociology, 28, 327-349.

51. National Conference of Catholic Bishops. (1997). Always our children: A pastoral message to parents of homosexual children and suggestions for pastoral ministers. Washington, DC: United States Catholic Conference. permission has been granted for this version to appear in e-Publications@Marquette. Taylor \& Francis (Routledge) does not grant permission for this article to be further copied/distributed or hosted elsewhere without the express permission from Taylor \& Francis (Routledge). 
52. Nicholosi, J. (1994). What does science teach about human sexuality? In S. B. Geis \& D. E. Messer (Eds.), Caught in the crossfire: Helping Christians debate homosexuality (pp. 67-77). Nashville, TN: Abingdon Press.

53. Nugent, R. (1988). Sexual orientation in Vatican thinking. In J. Gramick and P. Furey (Eds.), The Vatican and homosexuality: Reactions to the "Letter to the bishops of the Catholic church on the pastoral care of homosexual persons" (pp. 48-58). New York, NY: Crossroad Publishing.

54. Olyan, S. M., \& Nussbaum, M. C. (Eds.). (1998). Sexual orientation and human rights in American religious discourse. New York, NY: Oxford University Press.

55. Pew Research Center. (2012). Religion and attitudes towards same-sex marriage. The Pew Forum on Religion \& Public Life. Retrieved from http://www.pewforum.org/Gay-Marriage-and-Homosexuality/Religionand-Attitudes-Toward-Same-Sex-Marriage.aspx

56. Pitt, R. N. (2010). "Still looking for my Jonathan": Gay Black men's management of religious and sexual identity conflicts. Journal of Homosexuality, 57, 39-53.

57. Rodriguez, E. M. (2010). At the intersection of church and gay: A review of the psychological research on gay and lesbian Christians. Journal of Homosexuality, 57, 5-38.

58. Rodriguez, E. M., \& Ouellette, S. C. (2000). Gay and lesbian Christians: Homosexual and religious identity integration in the members and participants of a gay-positive church. Journal for the Scientific Study of Religion, 39(3), 333-347.

59. Rodríguez-Rust, P. C. (Ed.). (2000). Bisexuality in the United States: A social science reader. New York, NY: Columbia University Press.

60. Rogers, E. F. (1998). Sanctification, homosexuality, and God's triune life. In S. M. Olyan \& M. C. Nussbaum (Eds.), Sexual orientation and human rights in American religious discourse (pp. 134-160). New York, NY: Oxford University Press.

Journal of Homosexuality, Vol. 61, No. 9 (2014): pg. 1215-1241. DOI. This article is @ Taylor \& Francis (Routledge) and permission has been granted for this version to appear in e-Publications@Marquette. Taylor \& Francis (Routledge) does not grant permission for this article to be further copied/distributed or hosted elsewhere without the express permission from Taylor \& Francis (Routledge). 
NOT THE PUBLISHED VERSION; this is the author's final, peer-reviewed manuscript. The published version may be accessed by following the link in the citation at the bottom of the page.

61. Rogers, E. F. (2011, May 11). Same-sex complementarity: A theology of marriage. The Christian Century. Retrieved from http://www.christiancentury.org/article/2011-04/same-sexcomplementarity

62. Rogers, J. (2009). Jesus, the Bible, and homosexuality: Explode the myths, heal the church, revised and expanded edition. Louisville, $\mathrm{KY}$ : Westminster John Knox Press.

63. Sayeed, A. (2006). Making political hay of sex and slavery: Kansas conservatism, feminism and the global regulation of sexual moralities. Feminist Review, 83, 119-131.

64. Scanzoni, L., \& Mollenkott, V. R. (1994). Is the homosexual my neighbor? A positive Christian response. San Francisco, CA: Harper.

65. Shively, M. G., \& De Cecco, J. P. (1977). Components of sexual identity. Journal of Homosexuality, 3, 41-48.

66. Shokeid, M. (1994). A gay synagogue in New York. New York, NY: Columbia University Press.

67. Solomon, M. (1995). A strange conjunction. In J. Magonet (Ed.), Jewish explorations of sexuality (pp. 75-82). Providence, RI: Berghahn Books.

68. Spong, J. S. (2004). Blessing gay and lesbian commitments. In A. Sullivan (Ed.), Same-sex marriage pro and con: A reader (pp. 67-71). New York, NY: Random House.

69. Stackhouse, M. L. (1998). The prophetic stand of the ecumenical churches on homosexuality. In S. M. Olyan \& M. C. Nussbaum (Eds.), Sexual orientation and human rights in American religious discourse (pp. 119133). New York, NY: Oxford University Press.

70. Stone, K. (2009). What the homosexuality debates really say about the Bible. In M. De La Torre (Ed.), Out of the shadows into the light (pp. 19-38). St. Louis, MO: Chalice Press.

Journal of Homosexuality, Vol. 61, No. 9 (2014): pg. 1215-1241. DOI. This article is @ Taylor \& Francis (Routledge) and permission has been granted for this version to appear in e-Publications@Marquette. Taylor \& Francis (Routledge) does not grant permission for this article to be further copied/distributed or hosted elsewhere without the express permission from Taylor \& Francis (Routledge). 
NOT THE PUBLISHED VERSION; this is the author's final, peer-reviewed manuscript. The published version may be accessed by following the link in the citation at the bottom of the page.

71. Strandskov, C. (2011). Being gay is a gift from god. Retrieved from http://cordeliaknits.typepad.com/my_weblog/

72. Stuart, E. (2003). Gay and lesbian theologies: Repetitions with critical difference. Burlington, VT: Ashgate Publishing.

73. Swidler, A. (Ed.). (1993). Homosexuality and world religions. Harrisburg, PA: Trinity Press International.

74. Tanis, J. (2003). Trans-gendered: Theology, ministry, and communities of faith. Cleveland, $\mathrm{OH}$ : Pilgrim Press.

75. Taywaditep, K. J., \& Stokes, J. P. (1998). Male bisexualities: A cluster analysis of men with bisexual experience. Journal of Psychology and Human Sexuality, 10(1), 15-41.

76. Thumma, S. (1991). Negotiating a religious identity: The case of the gay evangelical. Sociological Analysis, 52(4), 333-347.

77. Tolman, D. L., \& Diamond, L. M. (2001). Desegregating sexuality research: Cultural and biological perspectives on gender and desire. Annual Review of Sex Research, 12, 33-74.

78. Umansky, E. M. (1997.) Jewish attitudes towards homosexuality: A review of contemporary sources. In G. D. Comstock \& S. E. Henking (Eds.), Que(e)erying religion: A critical anthology (pp. 181-187). New York, NY: Continuum.

79. Unterman, A. (1995). Judaism and homosexuality: Some Orthodox perspectives. In J. Magonet (Ed.), Jewish explorations of sexuality ( $p p$ 67-74). Providence, RI: Berghahn Books.

80. Wahba, R. (1989). Hiding is unhealthy for the soul. In C. Balka and A. Rose (Eds.), Twice blessed: On being lesbian, gay and Jewish (pp. 48-56). Boston, MA: Beacon Press.

81. Warner, R. S. (1995). The Metropolitan Community Churches and the gay agenda: The power of Pentecostalism and essentialism. Religion and the Social Order, 5, 81-108.

Journal of Homosexuality, Vol. 61, No. 9 (2014): pg. 1215-1241. DOI. This article is @ Taylor \& Francis (Routledge) and permission has been granted for this version to appear in e-Publications@Marquette. Taylor \& Francis (Routledge) does not grant permission for this article to be further copied/distributed or hosted elsewhere without the express permission from Taylor \& Francis (Routledge). 
NOT THE PUBLISHED VERSION; this is the author's final, peer-reviewed manuscript. The published version may be accessed by following the link in the citation at the bottom of the page.

82. Weinberg, M. S., Williams, C. J., \& Pryor, D. W. (1994). Dual attraction: Understanding bisexuality. New York, NY: Oxford University Press.

83. Weiner, B., Perry, R., \& Magnusson, J. (1988). An attributional analysis of reactions to stigmas. Journal of Personality and Social Psychology, 55, 738-748.

84. Whalen, R. E., Geary, D. C., \& Johnson, F. (1990). Models of sexuality. In D. P. McWhirter, S. A. Sanders, \& J. M. Rachover Reinisch (Eds.), Homosexuality/heterosexuality: Concepts of sexual orientation (pp. 61-70). New York, NY: Oxford University Press.

85. White, H. R. (2008). Proclaiming liberation: The historical roots of LGBT religious organizing, 1946-1976. Nova Religio: Journal of Alternative and Emergent Religions, 11, 102-119.

86. Wilcox, M. M. (2003). Coming out in Christianity: Religion, identity, and community. Bloomington, IN: Indiana University Press.

87. Williams, R. H. (Ed.). (1997). Cultural wars in American politics: Critical reviews of a popular myth. New York, NY: Aldine de Gruyter.

88. Wolkomir, M. (2006). Be not deceived: The sacred and sexual struggles of gay and ex-gay Christian men. New Brunswick, NJ: Rutgers University Press.

89. Yamane, D. (1997). Secularization on trial: In defense of a neosecularization paradigm. Journal for the Scientific Study of Religion, $36,109-22$.

90. Yip, A. K. T. (2002). The persistence of faith among nonheterosexual Christians: Evidence for the neosecularization thesis of religious transformation. Journal for the Scientific Study of Religion, 41, 199212. 
NOT THE PUBLISHED VERSION; this is the author's final, peer-reviewed manuscript. The published version may be accessed by following the link in the citation at the bottom of the page.

FIGURE 1: Religious Views of Homosexuality

\begin{tabular}{|l|l|l|l|l|l|}
\hline \multicolumn{2}{|l|}{ HOMONEGATIVE } & \multicolumn{2}{l|}{ MODERATE } & \multicolumn{2}{l|}{ HOMOPOSITIVE } \\
\hline $\begin{array}{l}\text { God Hates } \\
\text { Fags }\end{array}$ & $\begin{array}{l}\text { Love the } \\
\text { Sinner, Hate } \\
\text { the Sin }\end{array}$ & $\begin{array}{l}\text { We Don't Talk } \\
\text { About That }\end{array}$ & $\begin{array}{l}\text { They Can't } \\
\text { Help It }\end{array}$ & $\begin{array}{l}\text { God's Good } \\
\text { Gift }\end{array}$ & $\begin{array}{l}\text { Godly } \\
\text { Calling }\end{array}$ \\
\hline
\end{tabular}

Journal of Homosexuality, Vol. 61, No. 9 (2014): pg. 1215-1241. DOI. This article is (C) Taylor \& Francis (Routledge) and permission has been granted for this version to appear in e-Publications@Marquette. Taylor \& Francis (Routledge) does not grant permission for this article to be further copied/distributed or hosted elsewhere without the express permission from Taylor \& Francis (Routledge). 
NOT THE PUBLISHED VERSION; this is the author's final, peer-reviewed manuscript. The published version may be accessed by following the link in the citation at the bottom of the page.

i For deeper understanding of views of homosexuality in multiple religious traditions, see Comstock \& Henking (1997), Swidler (1993), Sullivan (2000), and Olyan \& Nussbaum (1997).

ii The greatest number of studies of these issues have been in Christian communities in the United States (Rodriguez 2010).

iii In recent years, "LGBT" has emerged as a common way to abbreviate "lesbian, gay, bisexual, and transgender." However, few of the sources I cite here consider bisexuals and even fewer consider trans people (or queers, who are sometimes also appended to this abbreviation). I reserve the use of this term for when it is accurate. A different survey of the literature would be necessary to do full justice to religious views of transgenderism and religious, trans people, but insofar as the trans category overlaps with lesbian/gay/bisexual/queer in challenging heteronormative assumptions, I include it.

iv I use the term "homonegative" as a neutral term to refer to groups or views that posit same-sex sexual activity, desire, and/or identity as sinful, sick, and/or wrong; I use the term "homopositive" to refer to groups or views that posit same-sex sexual activity, desire, and/or identity as good, healthy and/or as potentially righteous as heterosexuality. Individuals may espouse a view, but I resist characterizing individuals with these terms, as they are more likely than institutions to change and may draw from a mix of views.

$\checkmark$ See also Bell \& Weinberg (1978), De Cecco \& Parker (1995), Fausto-Sterling (2000), Jenkins (2010), Kinsey et al (1948), Klein, Sepekoff \& Wolf (1985), Laumann et al (1994), Rodríguez-Rust (2000), Shively \& De Cecco (1977), Taywaditep \& Stokes (1998), Tolman \& Diamond 2001, Weinberg, Williams \& Pryor (1994), Whalen, Geary \& Johnson (1990).

${ }^{v i}$ In the Protestant context, this is often referred to as a difference between "literalist/fundamentalist" and "historical-contextual" (or "historicalcritical") hermeneutics (Goss, 1993; Thumma, 1991; Rodriguez \& Ouellette, 2000), another false dichotomy. Most people who use scripture as a spiritual guide take some parts of it at face value and believe that other parts can only be understood in light of the context from which they come. Furthermore, beliefs are not dictated by denomination; this range of views can be found within many Christian and Jewish groups.

vii It should be noted that these views are not equally widespread or equally subject to internal variation, so summarizing the discussions does not require that each occupy equal space. permission has been granted for this version to appear in e-Publications@ Marquette. Taylor \& Francis (Routledge) does not grant permission for this article to be further copied/distributed or hosted elsewhere without the express permission from Taylor \& Francis (Routledge). 
viii We should note that in 2012, the director of the "flagship" ex-gay organization, Exodus, prompted controversy by rejecting the group's claim that it could change people's sexual desires and saying that it would emphasize helping members to avoid sexual behaviors the group saw as sinful (Gritz, 2012), thus coming to resemble the third variation in this category, described next. He then shut Exodus down in 2013 , citing abuses within the ministries under its umbrella and the tendency of churches to use the organization to avoid having to deal with their own anxieties about their members who experienced samesex attractions. Many ex-gay ministries formerly under the Exodus umbrella continue, and at the time of this printing, much is up in the air in the ex-gay movement.

ix Farley (1998) points out that the Catholic Church now allows that marital sex need not be procreative to be acceptable; infertile or postmenopausal couples are not forbidden from having sex. However, the demand for procreativity reemerges in discussions of homosexuality.

× Examples are too numerous to enumerate here, but see for instance, Boswell (1980), Comstock \& Henking (1997), Goss (1993), Jordan (2002), Lee (2012), Magonet (1995), Olyan \& Nussbaum (1998), Rogers (2009), Stone (2009), Tanis (2003).

xi This passage also exemplifies that the difference between official and everyday positions is most clear among US Catholics, who have reported greater proportions of supporters for LGBT rights than Protestants and Jews in surveys since the 1970s (Maher, Sever \& Pichler, 2008, pp. 331-334; Pew Research Center, 2012).

xii The language of the "calling" appeals to evangelical Protestants more than others, but I use it to bring out a religious language of volition that is present in some queer theologies. Unlike the labels I use for other types, it is not a term many of those represented in this section would use themselves.

Journal of Homosexuality, Vol. 61, No. 9 (2014): pg. 1215-1241. DOI. This article is @ Taylor \& Francis (Routledge) and permission has been granted for this version to appear in e-Publications@ Marquette. Taylor \& Francis (Routledge) does not grant permission for this article to be further copied/distributed or hosted elsewhere without the express permission from Taylor \& Francis (Routledge). 